\title{
IMPOVING STUDENTS' READING COMPREHENSION THROUGH COOPERATIVE LEARNING STRATEGY
}

\author{
PENINGKATAN PEMAHAMAN MEMBACA SISWA DENGAN MENGGUNAKAN \\ PEMBELAJARAN KOOPERATIF LEARNIG
}

\author{
ENENG LIAH KHORIAH, DEDE IMTIHANUDIN
}

\author{
Sekolah Tinggi Keguruan dan IImu Pendidikan Syekh Manshur \\ Jalan Raya Labuan Km 5 Kadulisung Pandeglang \\ Ponsel : 083893165435 \\ Surel : Nengkhoir03@gmail.com
}

\begin{abstract}
The purpose of this research is to know whether cooperative learning can be used to improve students' reading comprehension at SMK Ma'arif NU Pandeglang. Research hypothesis is to improve students' reading comprehension through cooperative learning strategy. The method used in this research was takes descriptive qualitative which use cycle model, there are: plan, action, observation and reflection and use a Classroom Action Research (CAR) method. The data is gathered by giving test, multiple choice, and questioner. The result of the test obviously infers that there is contribution of using cooperative learning in improving students reading comprehension because have different score between cycle one and cycle two and get score hight than cycle one.
\end{abstract}

Keywords: Reading Comprehension, Cooperative Learning

\begin{abstract}
Abstrak
Tujuan dari penelitian ini adalah untuk mengetahui apakah pembelajaran kooperatif dapat digunakan untuk meningkatkan pemahaman membaca siswa di SMK Ma'arif NU Pandeglang. Hipotesis penelitian yaitu terdapat peningkatan pemahaman membaca siswa melalui strategi pembelajaran kooperatif. Metode yang digunakan dalam penelitian ini adalah deskriptif kualitatif yang menggunakan model siklus yaitu: perencanaan, tindakan, observasi dan refleksi dan menggunakan metode Penelitian Tindakan Kelas (PTK). Data dikumpulkan dengan memberikan tes, pilihan ganda, kuesioner. Hasil tes dapat disimpulkan bahwa terdapat kontribusi menggunakan pembelajaran kooperatif dalam meningkatkan pemahaman membaca siswa. Karena terdapat perbedaan score antara siklus pertama dan siklus ke dua dan mendapatkan nilai yg tinggi dibandingkan dengan siklus pertama.
\end{abstract}

Kata kunci: Pemahaman Membaca, Pembelajaran Kooperatif 


\section{INTRODUCTION}

English is very important for human's social development as English holds the key as international language. English is a tool of communication of peoples of the world to get trade, social culture, science, and technology goals. Moreover, English is also important for career development, therefore, students need to understand and use English to improve their confidence to face global competition and performance it is known that there are four language skill, they are listening, speaking, reading and writing.

Reading is the ability of an individual to recognize a visual form with a sound or meaning acquired in the past, and on the thesis of the past experience, understanding and interpreting its meaning. In our society as knowledge rapidly accumulates and is committed to print greater demands are continually being made on the ability of people to read. Reading is a most important activity in any language class, not only as a source of information and a pleasurable activity but also as a means of console dating and extending one's knowledge of the language. Text and reader are two physical entities necessary for the reading process to begin. It is, however, the interaction between the text and reader that constitutes actual reading. Reading is interactive the reader makes use of information from his background knowledge as well as information from the printed page.

Based on the backgroud of problems above, the writer identifies some of the problems those are, faced by the students when they are reading as follow: students have low comprehension in the reading text based on the result beacause they are got low score so we must give strategy how to efective strategy, students don't know the effective strategy in reading comprehension. So they don't unserstand of text. And than students don't get meaningful in the reading text because they are lack of vocabluaries.

Some reserch problems may arise since many factors are involved. Those problems are formulated in question, which parentally appear: Can Cooperative Learning be used to improve students' reading comprehension at SMK Ma'arif NU Pandeglang? Because as we know not yet reserch about cooperative learning strategy by using snowball throwing and I hope with this reserch can give information about technique in 
teaching reading comprehension by using cooperarive learning strategy especialy snowball throwing. And can give contribution for english teacher to enrich knowladge in the technique reading comprehension, moreover as a contribution for students they will be more encaurage to read English with their friends especially in reading comprehension.

In line with formulation of problems above, the object of the reserch are as follow: To know whether cooperative learning can be used to improve student's reading comprehension at SMK MA'arif NU Pandeglang.

\section{THEORETICAL FRAMEWORK}

Reading is an active cognitive process of interacting print and monitoring comprehension to establish meaning. Reading is the instantaneous recognition of various written symbols, simultaneous association of these symbols with exiting knowledge, comprehension of the information and ideas communicated.

Reading is an active process because it involves and interaction between thought and language. It means that the reader bring to the task a formidable amount of information and ideas, attitude and believes.
Reading is active, productive, and cognitive activities. Reading involves an active search for information and interaction with the text. It requires the constant constructive involvement of the reader in what he is doing and it requires the use of senior high school abilities. thus, the more of each of his characteristics that is present in the reader during reading, the better the quality of his reading ability.

There are different types of reading such as silent reading, Intensive Reading, Extensive Reading, scanning, skimming, reading aloud and etc. in those many definition of the as follow:

Silent Reading is a reading process which done to get more comprehension in reading (Ma'mur 2006: 10). Silent reading can be with aloud reading by the teacher. The teacher's is a model in accuracy and expressiveness. It is though that the great amount of interest in reading is secured by a happy combination of reading aloud by learners, reading aloud by the teacher and silent reading by the learners.

Extensive reading program will actively promote reading out of class, class time is always in short supply and the amount of reading needs to 
achieve fluency and efficiency undertake to themselves. The intensive reading generally involves longer selection which is read outside of class, it may be advisable to delay extensive reading until one in sure that the students are grasping and employing concepts being presented and reinforced in both components of the reading it develops the student ability in reading directly and fluency in the target language for enjoyment without the aid of the teacher. Extensive reading is the best possible way for students to develop automatically that is the automatic recognition of words when they see them. It is by far the best way to improve their English reading (and writing) overall (Harmer 2001:204). Extensive reading also process to improve reading.

Reading passage can be used for consolidating structure and vocabulary as a springboard for other classroom activities, to increase pupil's passive vocabulary and for pleasure.

Scanning in contrast, is defined as the ability to locate specific information or fact as rapidly as possible. Glancing at a selection for a specific piece of information and stopping when you find it. Generally, when you scan for information you know what you are looking for before you begin to read. For example, you scan the $S$ column in the telephone book looking for Joe Santiago's number. Scanning is teaching used when locating a word in the dictionary, when seeking a page number in the index or when checking to see what television programs are offered in certain times. Good scanning ability dependents on knowing what you want to find and knowing the organization of the material to be read. Scanning is something you already know to do, but you may or may not be very proficient at it. (naf'an and miftahul, 2010: 52-53)

Skimming is defined as the ability to identify them main ideas while very rapidly and selectively skipping over the reading material. We pass our eyes quickly over an entire selection to get a general idea of "gist" of its contents. For example, you skin of chapter in your history books to review your knowledge of the civil war or may be you want order some food by hooking at the menu. It can be said that we don't know what material is before we read it. Skimming and scanning are both very rapid reading technique. But skimming is technique used to find out how a news story, magazine article, or textbook chapter is organized and what is it generally 
about without having to read the entire selection. To skim correctly it is necessary to know the various organizational patterns of writing. (naf'al and miftahul, 2010:52-53).

A reading aloud is a planned oral reading of a book or print excerpt, usually related to a theme or topic of study. The reading aloud can be used to engage the students listen while developing background knowledge, increasing comprehension skills, and fostering critical thinking. A reading aloud can be used to model the use of reading strategies that aid in comprehension (naf'an and miftahul, 2004:45). Cooperative Strategies, one of them cooperative learning is basically from indirect strategies such as metacognitive strategies, affective strategies and social strategy. As we know cooperative learning part of social strategy. Cooperative Learning is a process, which makes students working together, helping each other, and sharing ideas, asking and giving information together (Salvia 1995:2) Cooperative learning is one strategy in teaching.

Manyn definition about cooperative language learning (CLL), Cooperative learning is part of more general instructional approach also known as collaborative learning (CL).
Cooperative Learning is an approach to teaching that makes maximum use of cooperative activities involving pairs and small groups of learns in the classroom (S. Rodges 2001:192). Cooperative learning is group learning activity organized so that learning is dependent on the socially structured exchange of information between learners in groups and in which each learner is held accountable for his or her own learning and is motivated to increase the learning of others.

Cooperative learning is founded on some basic premises about the interactive/cooperative nature of language and language learning and builds on these premises in several. Cooperative Learning is working together to accomplish shared goals. Cooperative Learning is carefully structured organized so that each learner interacts with other and all learners are motivation to increase each other's learning. Cooperative learning essentially involves students learning from each other in group. But, it is not group configuration that makes cooperative learning distinctive; it is the way that students and teachers work together that is important. As we have just seen, with learning strategy training, the teacher helps students learn how to learn more effectively. 
In cooperative learning, teacher teaches students collaborative or social skill so that they can work together more effectively. Indeed, cooperation is not only way of learning, but also a theme to be communicated about and studied (Jacobs 1998) (Diane Larsen Freeman 2000:164).

Positive independence occurs when the gains for one individual are associated with gains for other; that is, when one student achieves, other benefits too. Positive independence is contrasted with negative Independence and Non independence. Positive independence can be created by the task structure, by the way out comes and or means are defined, either goal or reward outcomes can determine positive independence. For example, having a single team product such as an essay, mural, or presentation to the class is goal structured independences. Reward structured independence can result from creating a team score averaged from individual scores or from the sum of the number of individuals teaching a predetermined criterion, among other possible. Role structured independence involves assigning different roles to each students within a group, such as "explainer" or checker" so that each has a specific responsibility. Independence is having a role that a group cannot progress to a new learning center or project until all students have completed the assignment. Both materials and rule structured independence stimulate students to interact. Defining specific roles can help specify the ways they will help each other.

Team formation positive independence implies that grouping has occurred, either by assignment or by chance. Students can group themselves; "leaders" can make turns selecting teammates; or teachers can assign students to teams. Informal or spontaneous grouping is less desirable in many situation than formal or planned grouping methods. Four types of formal team formation heterogeneous, random, interest and homogenous/heterogeneous language ability are described here. Heterogeneous grouping can vary along several dimensions. The maximally heterogeneous team mirrors the classroom composition. It includes, to the extent possible, achievement level, gender, ethnic, and linguistics dimensions. Heterogeneous teams can be created with a ranked list of students by following three steps; First, Rank students from highest to lowest achiever (in order of preference) 
present, recent posttests, past grades, Bess guess. Second Assign the top, bottom and middle two achievers to the first team and remove from the. Third, repeat steep 2 to create the next teams.

Random grouping can be based on distributing tokens, such as colored paper, shapes, or playing card. Students with similar tokens from teams (triangles go together; aces from a team, for example). Numbering of according to group size or using table of random numbers also results in random grouping. Interest grouping is based on students' characteristics other than achievement, gender, ethnicity, race, or language proficiency, although this factor may be considered. (Based on Kagan, 1989) random groping is process classification of group consider this to be a defining characteristics of $\mathrm{CL}$.

Social skill includes ways students interact with each other to achieve activity or task objectives (e.g asking and explaining) and ways students interact as.

Structures are generic, contentfree ways of organizing students interactions with content and with each other. For example, (STEP 1) one students talks while others listen, then (STEP 2) the next student's talks, etc. structures describe different ways students are to interact.

Although there is general agreement on the importance of the above elements, there is considerable variation in the emphasis accorder to size of groups, team building, process/product, awareness/mastery, grading system, and the role of the teacher.

In traditional classroom, the ration of information-giver, usually the teacher, to information-receivers, the students, is typically one to twenty five or thirty. Cooperative groups can provide a dramatically higher ratio of information giver to informationreceivers, including one to one for work in pairs.

Team building procedures can include having students choose a team name, symbol, and cheer; or interviewing teammates on topics related to the subject material to be covered. Class building methods include building a positive class identify-by creating a class banner, for example-but also include procedures such as inside-outside circle, explained later in the chapter.

Some CLL methods emphasize basic skill, while others emphasize higher order thinking processes. The interactive aspects of CLL can be of 
value even in discrete skill-building tasks. Focus on discrete knowledge allows students to explore the interactions process at hand, such as specific cooperating or language skills. Aspects of the interaction process may be emphasizing, as in the use of special "processing" worksheets with which students evaluate how they cooperated, encourage, and explained. Many lesson objectives are oriented toward mastery of basic skill or other information, emphasizing "final draft" or "public publication" kinds of product.

Others emphasize developing familiarity and awareness, encouraging "publication" or "rough draft" interaction.

A "prepublication" emphasis can increase awareness of content material without the immediacy of pressure to reach levels. Also, a preliminary, prepublication, approach may be used to concentrate attention on content rather than on linguistics correctness (Olsen and Reer, 1984). Basically for awareness/ mastery must conduct with prepublication and interaction.

The teacher's role is generally one of facilitating, monitoring student's engagement with process, or clarifying information, rather than primarily one of providing information.
Snowball Throwing is more creativity of students learning. Snowball throwing is one of strategy cooperative language especially grouping. Snowball throwing is one of vocabulary games make students enjoy and can decrease in learning. Snowball throwing have affective on the students memory development. Snowball Throwing is learning that can be used to provide learning materials that are difficult concept to students and can be used to determine the extent of knowledge and skills of students in such materials. Snowball throwing in the learning model students formed into groups that represented the group leader for pushing given the task of the teacher, then each student create a question that was shaped like a ball (question paper) and the thrown to the other students, each student answered the question of the ball obtained.

Teaching reading through snowball throwing is a process complex to learn in the class room. The teacher can approach to students to know everything because as we know snowball throwing is one of part cooperative learning and more aspect key cooperative learning in the snowball throwing such as positive independence, team formation, 
accountability, social skill, structures and structuring, others elements, group size, team building, process, awareness, grading, role teacher and game, so the writer using snowball throwing in the learning especially cooperative learning strategy in the class. Beside it I thinnk using snowball throwing is better for the teaching reading comprehension beacuse has aspect of cooperative in the teach.

Snowball throwing is one process creative learning because the all has aspect for study and more easy to undesrtand for the study. We can share with students, and students can share with the other his friends, for the leader can accauntability for the group with assessmenent of teacher, has good team formation, and etc. Snowball throwing learning model trains students to be more responsive to receive the message from other, and convey the messaage to his friends in a group. Throw the question does not use a stick learning model but the use of paper with the question of paper crumpled into a ball and then threw to the other students. Students who got the ball then open the paper and answer the question.

Here are some steps in carrying out the snowball throwing in the class room:
2.5.1 teacher delivers material to be presented.

2.5.2 teacher forms groups and call the head of the group to give an explanation about the material.

2.5.3 Each head of the groups heads back to his group respectively and then explain the material which has been explained by teacher to their groups.

2.5.4 then, each students is given on the sheet of work paper, to write down one question concerning any matter which has been described by the group leader

2.5.5 then, paper containing the question was made into a ball and throw $\mathrm{n}$ from one student to another student for approximately 15 minutes.

2.5.6 after students got the ball/ one question is given the opportunity for students to answer question that are written in ball-shaped paper are alternately.

\subsubsection{Evaluation \\ 2.5.8 Closing}

Snowball throwing method is one of vocabluary games make students enjoy and can decrease in learning vocabluary. Snowball throwing encaurages the students to be active in reading in the classroom. Snowball throwing haves positive affective on 
the students memory development. In addition, his purpose of this technique is appropriate in reviewing the vocabulary for the students.

The advantages of Snowball Throwing, they are:

2.6.1 this method can make the players or in this case the students more adroit and their ability about memorizing the English vocabluary is more increased because they learn in an enjoyable way

2.6.2 it is make fun in learning with snowball throwing brings real word context in to the classroom and enhances students to use english in flexible communicative way

2.6.3 it can make students relax and fun study beside it the students can share with the other friends in the group

2.6.4 the teaching leraning process more attractive

2.6.5 the teacher easier to teach about the reading comprehension

Snowball throwing also have disadvantages in the method because in this class the teacher need much of time for finished teach.

The disadvantages of snowball throwing, they are:

2.7.1 this method need a lot of time to finish all the picture, because if the students can't answer so the teacher should continoue to another students 2.7.2 the teacher should control the situation of classroom, this method will make situation more crowded because the students will scream when the ball running

2.7.3 this method needs the room of large

\section{METHODOLOGY OF RESEARCH}

Method is implemented in the classroom through what are called technique. The method is classroom action reserch that Carr and Kemmis (McNiff, 1988:2) Classroom Action reserch is one of them method of reserch. descriptively stated that:

Clasroom Action reserch is as a form of self reflective enquiry undertaken by participants (teachers, students or participant) example in social including educational situations in order to improve the rationality and justice of (a) their own social or educational practices (b) their understanding of these practices, and (c) the situations in which these practices are charred out (Departement Pendidikan Nasional, materi pembelajaran terintegrasi Bahasa Inggris. 2005:7. the systmatic collection and analysis of data relating to the improvement of some area of 
profesional practice. It is often considered the most accesible form of reserch for teacher, because its goal is the solution of problem encauntered in everyday practice (Phil Benson 2001:192). Basically Reserch must be systematic and must professional practice. Classroom action reserch is simply a form of self-reflective enquiry undertaken by participants in social situations in order to improve the retionality and justice of their own practicies, their understand of these practices, and the situations in which these practices are carried out ( Burns 1999:153).

The subject of the reserch is the Tenth Grade of SMK Ma'arif Nu Pandeglang-Banten. This class consist of 27 (twenty seventh) students. Male consist of 17 students and female 10 students.

The writer conducted a field research at SMK NU Ma'arif Pandeglang which done on Maret 14th-April4th 2017. This school located in Jalan Raya Labuan Km 3 Majasari Saruni Pandeglang

\section{THE RESULT OF THE RESERCH}

During the implementation of learning process in the classroom activity in cycle two, the observer kept observing the teaching and learning in the class. Started from third and forth meeting in the cycle two. The resulth students score of reading comprehension test on narrative text showed that the improvement that before. It means that the score was better than before. Score of cycel 2 Mean 71, 85 (B/ Good), Median 70, Mode 70 and standar deviation 96,22. The resulth showed that maximum score was 90 , minimum score was 60 , average score was 71,85 score description was B (Good). It means that, students' score of reading comprehension test was improving than before. This score was achieved the target score of KKM (Standart Criteria Minimum)

\section{Table}

\section{The students score of reading} comprehension test in the second cycle

\begin{tabular}{|c|c|c|c|}
\hline Mode & Median & Mean & STD \\
\hline $\mathbf{7 0}$ & $\mathbf{7 0}$ & $\mathbf{7 1 , 8 5}$ & $\mathbf{9 6 , 2 2}$ \\
\hline
\end{tabular}

Finally from the explanation, we have known that there are movement between the first and second cycle in improving students' reading comprehension through cooperative learning. The mean score of cycle one is $58,33 / \mathrm{D}$ (low), the mean score of the second cycle is $71,85 / B$ (Good). The data above indicates that the 
application of cooperative learning can improve students' reading comprehension. The students score improvment can be said as the result of applying or using cooperative learning which it applied in two cycle. Thus, the writer can conclude that using cooperative learning can improving students' reading comprehension on the text.

\section{CONCLUSION}

Based on the reserch, the writer concludes, that cooperative learning can improve the students reading comprehension at SMK Ma'arif $\mathrm{Nu}$ Pandeglang there is the contribution of using cooperative learning strategy in students reading comprehension on the text. It can be seen from the score first cycle and second cycle, for first cycle mode 50, median 55, Mean 58,33, and STD 12,55. And second cycle the result are mode 70 , median 70 , mean 71,85 , STD 96,22. It's mean that using cooperative learning by using snawball throwing gives contribution in improving students' reading comprehension.

\section{REFERENCESS}

Aebersold, Jo Ann And Marry Field. from Reader to Reading
Teacher: Issues and Strategies for Second Language Classroom. Cambridge:

Cambridge University Press, 1997.

Anderson Jonathan et.al. efficient reading. The University of New England,1969.

Bension Phil. Teaching and Research Automy in Language Learning.England: Pearson Education Press, 2001.

Burns, Anne. Collaborative Action Research for English Language Teacher: Cambridge University Press, 1999.

Departement Pendidikan Nasional: materi. pembelajaran terintegrasi Bahasa Inggris 2005.

Diane Larsen-freeman. Techniques and principles in Language Teaching: Oxpord University Press, 2000.

Harmer Jeremy. How to Teach English. Cambridge: Longman, 2001.

Kessler, Carolyn. Cooperative Language Learning. (Engleweed Cliffs, New Jersey), 1992.

K. Klingner, Janette K, Sharom Vaughn, and Alison Boardman. Teaching Reading Comprehension to Students with Learning Difficulties. New York 
London : The Guilford Press, 2007.

Kristin Lems, Leah D. Miller, Tenena

M. Soro. Teaching Reading to

English Language: Learners Insinght From Linguistics, USA: The Guilford Press, 2010.

McNamara, Danielle,S. Reading Comprehension Strategies:

Theories, Intervention, and Technologies, USA: Lawrence Erlbaum Associates, 2007.

McNiff. Jean and Jack Whitehead.Action Research:

Principles and practice; Second Edition, London and New York: Routladge Famer, 2002.

Ma'mur, Ilzamuddin. Pijar-Pijar Pemikiran Bahasa dan Budaya, Jakarta: Diadit Media, 2006.

Miftahul Rachmat, Naf'an Tarihoran.

Reading Basic Reading Skills, Serang: Loquen Press, 2010.

Nunan, David.Second Language Teaching and Learning. Boston: Heinle \& Heinle Publishers, 1999.

Nasution,I.S.P, Teaching ESL/EFL.

Reading and Writing. New York:

Routladge, 2009.

Pamela, J. Farris.Teaching Reading: A Balanced Approach for Today's Classroom, New York: McGrawHill, 2004.
Rivers Wilga M. Interactive Language Teaching,

(Cambridge:

Cambridge University Press), 1987.

William, Grabe. Reading in a Second Language: Moving From Theory to Practice, USA: Cambridge University Press, 2009.

Wilga M. Rivers. Teaching Foreign Language: Second Edition, USA: The University of Chicago Press, 1981. 